\title{
Bond Performance of Sanded Surface and Threaded Smooth Gfrp Bars
}

\author{
Antony Kodsy ${ }^{1 *}$ and George Morcous ${ }^{2 *}$ \\ ${ }^{1}$ Graduate Research Assistant, University of Nebraska, USA
}

${ }^{2}$ Professor of Construction Engineering, University of Nebraska, USA

Submission: June 11, 2019; Published: June 28, 2019

*Corresponding author: Antony Kodsy, Graduate Research Assistant, University of Nebraska, 1110 S. 67th Street, Omaha, NE, USA

George Morcous, Professor of Construction Engineering, University of Nebraska, 1110 S. 67th Street, Omaha, NE, USA

\begin{abstract}
This article presents the findings of experimental testing done at the University of Nebraska structures lab on bond performance of three types of GFRP bars. Specimens with $0.43 \mathrm{in} .(11 \mathrm{~mm})$ and $0.55 \mathrm{in} .(14 \mathrm{~mm})$ diameter with sanded surface, in addition to specimens with $0.43 \mathrm{in}$. $(11 \mathrm{~mm})$ diameter threaded surface were tested by pullout. Threaded surface bars bond strength was 2.5 and 1.8 times the $0.43 \mathrm{in}$. ( $11 \mathrm{~mm})$ and $14 \mathrm{~mm}$ (0.55in.) diameter sanded surface bars respectively. Measured bond strength results were compared against the required ACI 440.1R-15 development length. The ACI requirement of the sanded surface bars was approximately double the measured required development length, and 2.6 times the measured required development length for the threaded specimens. Threaded surface bars bond strength was also compared against previous results for helical and ribbed bars and exceeded them. This lead to the conclusion that threading the GFRP bar without the need to roughen its surface by sanding can be an efficient technique in increasing the bond strength. In addition, the use of GFRP nuts as an accessory can have several applications like bar splices or end anchors and can be advantageous to structural engineers in reinforcement detailing and reducing development length.
\end{abstract}

Keywords: GFRP; Bond; Sanded; Threaded; Nut

\section{Introduction}

Steel Reinforcement corrosion has been reported to be a major contributor in the deterioration of concrete structures. The use of FRP bars as reinforcement in concrete structures has proven to provide an effective solution for this durability issue [1]. The physical and mechanical properties and surface shape of GFRP bars are significantly different from steel bars. This difference cause GFRP bars to have lower bonding properties with concrete than steel bars causing bond performance to be a major concern when designing GFRP reinforced concrete elements [2]. Several pullout tests have been done to evaluate bond strength of FRP bars which is a major factor in estimating development length [3-5]. The ACI 440.1R-15 [3] defines development length as the embedment in concrete required to transfer the force in the bar through bond (equation 10.1a). The used GFRP bars in this study had a guaranteed tensile strength (mean tensile strength of test specimens minus three times standard deviation [3] of $121 \mathrm{ksi}$ ( $834 \mathrm{MPa}$ ). This value falls within the range of the ACI 440.1R-15 GFRP bar tensile strength values of 70 to $230 \mathrm{ksi}$ (483 to $690 \mathrm{MPa}$ ).
Discussion and Results

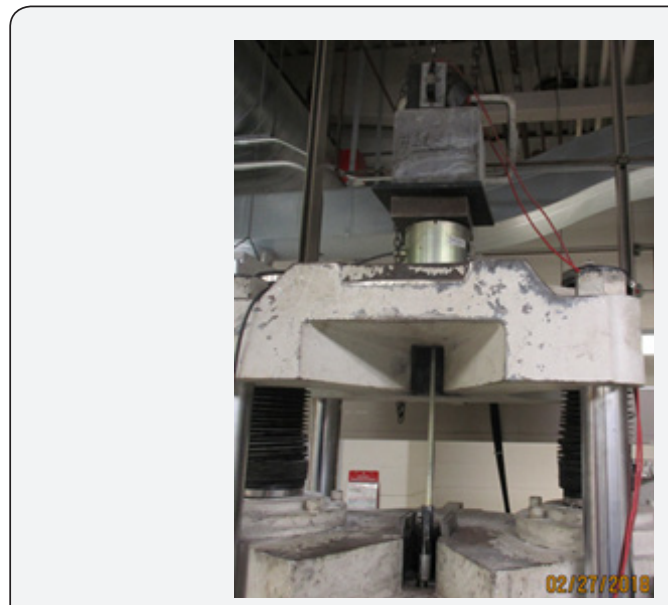

Figure 1: Test setup for a sample $11 \mathrm{~mm}$ diameter sanded surface specimen.

In this study three different types of GFRP bar surfaces were considered with a total of 16 specimens. Specimens included six $0.43 \mathrm{in}$. (11 mm) diameter plain bars (sanded surface), and 
six specimens of $0.43 \mathrm{in}$. $(11 \mathrm{~mm})$ diameter threaded GFRP bars (smooth surface), in addition to four specimens of $0.55 \mathrm{in}$. (14mm) diameter plain GFRP bars (sanded surface). Specimens were tested according to ACI 440.3R-12 test method for bond strength of FRP bars by pullout testing [6].

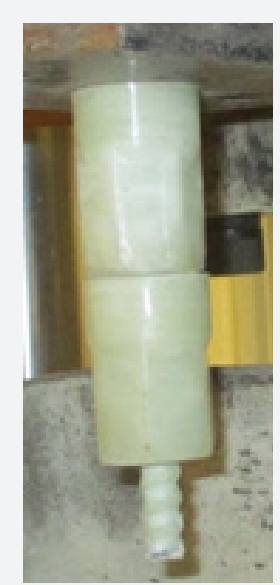

Figure 2: Using two nuts with the threaded surface bar to apply the pullout force by bearing on the nuts.

Concrete cubes with a side length of 8 inches $(20 \mathrm{~mm})$ were cast around GFRP bars with a bonded length of 5 times bar diameter. In order to create the bonded length, hollow polyvinyl chloride (PVC) tubes were placed at the top of the block to de-bond the required portion of the contact length. Average concrete compressive strength was $10 \mathrm{ksi}(69 \mathrm{MPa})$ at the time of testing. Specimens were mounted on top of $120 \mathrm{kip}(533 \mathrm{kN})$ Universal Testing Machine as shown in Figure 1. A load cell and

Table 1: Summary of test results.

\begin{tabular}{|c|c|c|c|c|c|c|}
\hline $\begin{array}{l}\text { Speci- } \\
\text { men ID }\end{array}$ & Surface Type & $\begin{array}{c}\text { GFRP Bar Diameter (in.) } \\
(\mathrm{mm})\end{array}$ & $\begin{array}{l}\text { Bonded Length (in.) } \\
\text { (mm) }\end{array}$ & $\begin{array}{l}\text { Required ACI 440.1R-15 } \\
\text { Development Length }\end{array}$ & $\begin{array}{l}\text { Bond Strength (psi) } \\
\text { (MPa) }\end{array}$ & Failure Mode \\
\hline \#11-1 & \multirow{5}{*}{ Sanded } & \multirow{5}{*}{$0.433(11)$} & \multirow{5}{*}{$5 . d_{b}$} & \multirow{5}{*}{$64 . d_{b}$} & $1177.0(8.1)$ & Slippage \\
\hline \#11-2 & & & & & $1177.0(8.1)$ & Slippage \\
\hline \#11-3 & & & & & $1280.3(8.8)$ & Slippage \\
\hline \#11-4 & & & & & $1177.0(8.1)$ & Slippage \\
\hline \multirow[t]{5}{*}{ \#11-5 } & & & & & $1053.1(7.3)$ & Slippage \\
\hline & \multicolumn{4}{|c|}{ Average } & $1172.9(8.1)$ & \\
\hline & \multicolumn{4}{|c|}{ Coefficient of Variation } & $6.90 \%$ & \\
\hline & \multicolumn{4}{|c|}{ Guaranteed Bond Strength } & $930.1(6.4)$ & \\
\hline & \multicolumn{4}{|c|}{ Measured Required Development Length } & $32.5 \mathrm{~d}_{\mathrm{b}}$ & \\
\hline \#11T-1 & \multirow{3}{*}{ Threaded } & \multirow{3}{*}{$0.433(11)$} & \multirow{3}{*}{$5 . d_{b}$} & \multirow{3}{*}{$64 . d_{b}$} & $2437(16.8)$ & Nut/Thread \\
\hline \#11T-2 & & & & & $3283(22.6)$ & Nut/Thread \\
\hline \multirow[t]{5}{*}{ \#11T-3 } & & & & & $2416(16.7)$ & Nut/Thread \\
\hline & \multicolumn{4}{|c|}{ Average } & $2711.9(18.7)$ & \\
\hline & \multicolumn{4}{|c|}{ Coefficient of Variation } & $18.20 \%$ & \\
\hline & \multicolumn{4}{|c|}{ Guaranteed Bond Strength } & $1231.2(8.5)$ & \\
\hline & \multicolumn{4}{|c|}{ Measured Required Development Length } & $24.6 \mathrm{~d}_{\mathrm{b}}$ & \\
\hline
\end{tabular}

two linear variable differential transforms (LVDTs) were used on top of the machine to measure applied load and slippage at bar free end. Load was applied by loading one end and pulling the bar at a rate of $0.05 \mathrm{in} . / \mathrm{min}$. $(1.25 \mathrm{~mm} / \mathrm{min}$.). For the sanded surface bars, metal sleeves were glued to the loaded end of the bar to allow for the machine clamps to grip on the bar. While for the threaded bars, GFRP nuts were used as a compatible product with the bar and load was applied to the bar by bearing on the nut as shown in Figure 2.

The ACI 440.3R-12 [6] recommends that loading shall be continued until rupture of the FRP bar or slippage of at least $0.1 \mathrm{in}$. $(2.5 \mathrm{~mm})$ occurs. Bond strength is then calculated according to the maximum recorded force divided by the bonded area of contact. Table 1 summarizes bond strength and failure modes for the tested specimens. Figure 3 shows load-slip plot for the sanded 0.433in. (11mm) diameter bar (\#11) specimens, the results of one specimen were removed from the data as it was considered an outlier. Figure 4 shows load-slip plot for the threaded 0.433in. (11mm) diameter bar (\#T11) specimens; three specimens were tested at first using one nut which could not cause any significant slippage and the failure mode occurred at the threads, these results were not considered. For the remaining three specimens, two nuts were used and could not cause a slippage failure also. However, using two nuts provided about double the bond strength of using one nut. Only the results of using two nuts were considered. Figure 5 shows load-slip plot for the sanded $0.55 \mathrm{in}$. $(14 \mathrm{~mm})$ diameter bars (\#14), all four specimens' results were considered. Figure 6 shows a comparison of the average bond strength for the tested specimens. 


\section{Civil Engineering Research Journal}

\begin{tabular}{|c|c|c|c|c|c|c|}
\hline \multirow{6}{*}{$\begin{array}{l}\# 14-1 \\
\# 14-2 \\
\# 14-3 \\
\# 14-4\end{array}$} & \multirow{4}{*}{ Sanded } & \multirow{4}{*}{$0.55(14)$} & \multirow{4}{*}{ 5. $d_{b}$} & \multirow{4}{*}{$64 . d_{b}$} & $1,421(9.8)$ & Slippage \\
\hline \multirow{2}{*}{$\begin{array}{l}\# 14-2 \\
\# 14-3\end{array}$} & & & & & $1,664(11.5)$ & Slippage \\
\hline & & & & & $1,357(9.4)$ & Slippage \\
\hline & & & & & $1,472(10.1)$ & Slippage \\
\hline & \multicolumn{4}{|c|}{ Average } & $1,479(10.2)$ & \\
\hline & \multicolumn{4}{|c|}{ Coefficient of Variation } & $9.00 \%$ & \\
\hline & \multicolumn{4}{|c|}{ Guaranteed Bond Strength } & $1079.7(7.4)$ & \\
\hline & \multicolumn{4}{|c|}{ Measured Required Development Length } & $28.0 \mathrm{~d}_{\mathrm{b}}$ & \\
\hline
\end{tabular}

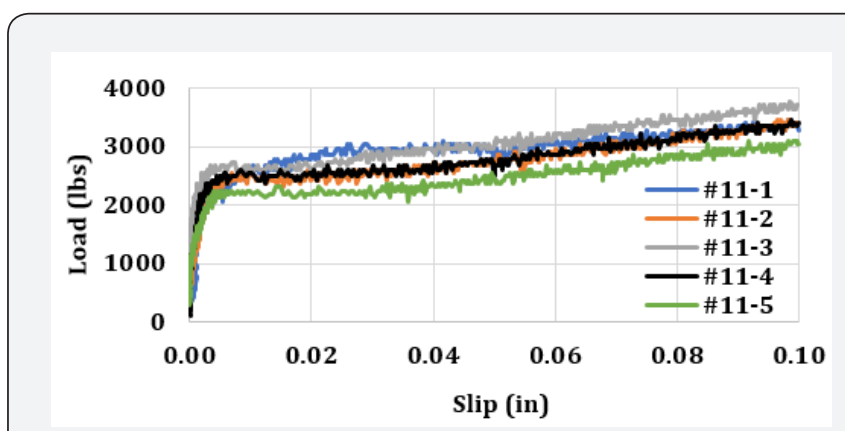

Figure 3: Load-slip plot for the $11 \mathrm{~mm}$ diameter sanded surface bars.

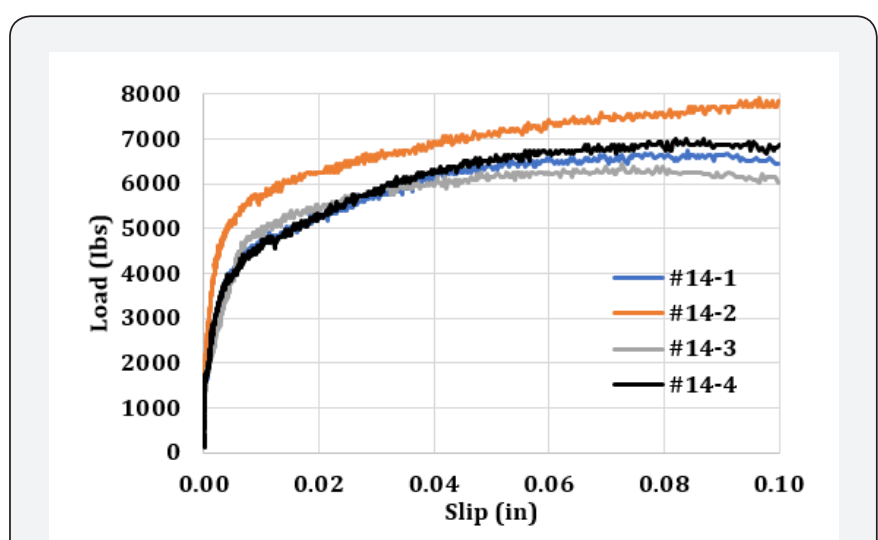

Figure 4: Load-slip plot for the $14 \mathrm{~mm}$ diameter sanded surface bars.

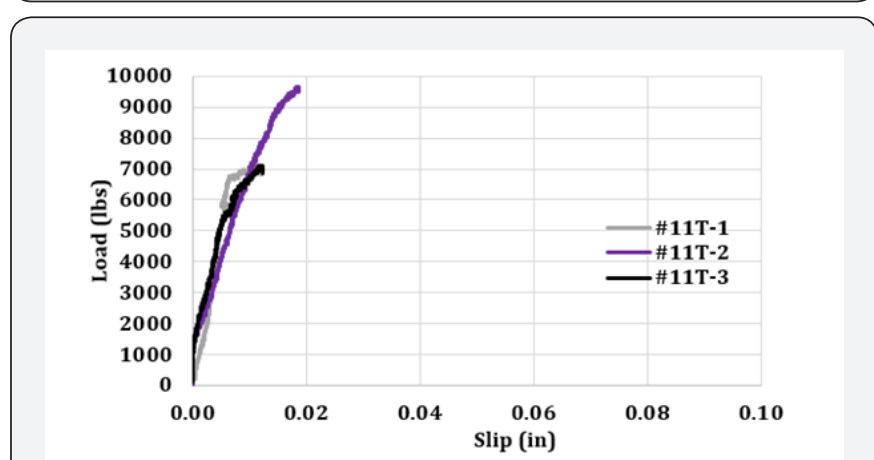

Figure 5: Load-slip plot for the $11 \mathrm{~mm}$ diameter threaded surface bars.

Guaranteed bond strength results were compared against the required ACI 440.1R-15 [3] development length using equation (10.3a). The parameter affecting development length are the transfer force (taken as the guaranteed tensile strength times bar area), concrete compressive strength, bar location modification factor (taken by 1), and the concrete cover to the center of the bar. The ACI requirement for the sanded surface bars was approximately double the measured development length, and 2.6 times the measured development length for the threaded specimens.

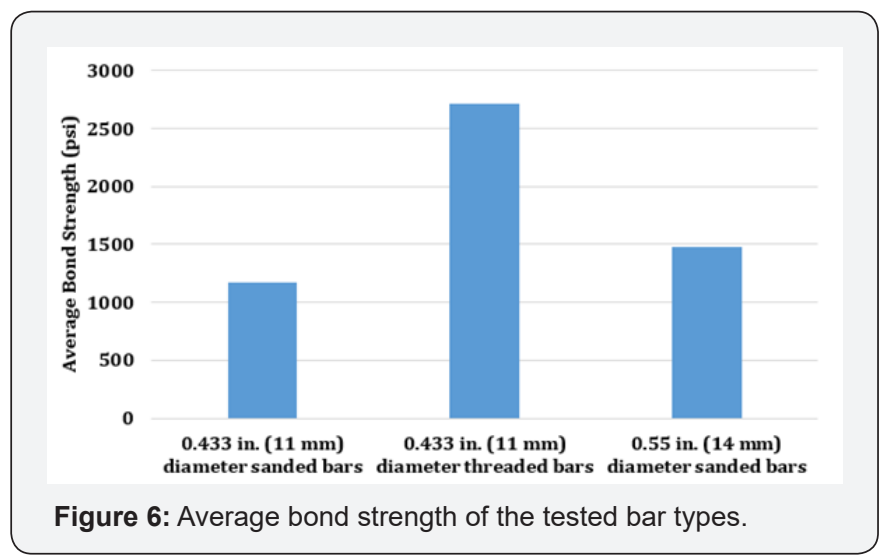

Resulting bond strength was compared against Katz et al. [4] where sanded FRP bars were tested after cyclic loading. The unloaded specimens had an average bond strength of $1.98 \mathrm{ksi}$ for sanded specimens with a helical fiber wrapped around the surface to enhance bond strength. Threaded specimens bond strength in this study resulted in about 1.37 times that value. Also bond strength was compared against Masmoudi et al. 2011 [5] where a commercial GFRP bar product with ribbed surface was tested for long-term bond performance under temperature ranging from $200{ }^{\circ} \mathrm{C}$ to $800{ }^{\circ} \mathrm{C}$. Bond strength under $200{ }^{\circ} \mathrm{C}$ temperature was highest. Threaded surface bars bond strength in this study was about 1.35 times the $0.31 \mathrm{in}$. (8mm) diameter bars under $200 \mathrm{C}$, and 1.6 times the $0.63 \mathrm{in} .(16 \mathrm{~mm})$ diameter bars under $200{ }^{\circ} \mathrm{C}$. This comparison shows the effectiveness of the considered threads in this study in increasing the bond strength compared to other threaded surfaces.

\section{Conclusion}

1. For 0.433in. $(11 \mathrm{~mm})$ and $0.55 \mathrm{in} .(14 \mathrm{~mm})$ diameter sanded GFRP bars, bond strengths were 1,173 (8.1) and 1,479 (10.2) psi (MPa) respectively which are comparable to other sanded surfaces. 


\section{Civil Engineering Research Journal}

2. For the 0.433in. $(11 \mathrm{~mm})$ diameter threaded GFRP bars, a significantly small slippage was measured as the specimens failed at the threads and/or nuts. Using two nuts yielded approximately 2.3 times the bond strength measured for sanded 0.433in. (11mm) diameter specimens.

3. Threaded bar surface is an efficient technique to increase bond strength compared to other bar roughening technique. And the use of the nut as an accessory can have several applications and advantages.

\section{References}

1. Wu C, Bai Y, Kwon S (2016) Improved Bond Behavior between GFRP rebar and Concrete using Calcium Sulfoaluminate. Construction and Building Materials 113: 897-904.

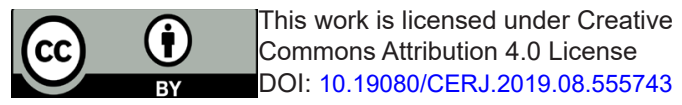

2. Yang S, Xu X, (2018) Discussion on Bonding Performance between FRP Bars and Concrete. International Conference on Civil and Hydraulic Engineering, China.

3. ACI Committee 440 (2015) Guide for the Design and Construction of Structural Concrete Reinforced with Fiber-Reinforced Polymer (FRP) Bars (ACI 440.1R-15), American Concrete Institute, Detroit.

4. A Katz (2000) Bond to Concrete of FRP Rebars after Cyclic Loading. Journal of Composites for Construction 4(3): 137-144.

5. Masmoudi R, Masmoudi A, Ouezdou M, Daoud A (2011) Long-term bond performance of GFRP bars in concrete under temperature ranging from $20^{\circ} \mathrm{C}$ to $80^{\circ} \mathrm{C}$. Construction and Building Materials 25: 486493.

6. ACI Committee 440 (2012) Guide Test Methods for Fiber-Reinforced Polymer (FRP) Composites for Reinforcing or Strengthening Concrete and Masonry Structures (ACI 440.3R-12), American Concrete Institute, Detroit.

\section{Your next submission with Juniper Publishers will reach you the below assets}

- Quality Editorial service

- Swift Peer Review

- Reprints availability

- E-prints Service

- Manuscript Podcast for convenient understanding

- Global attainment for your research

- Manuscript accessibility in different formats

( Pdf, E-pub, Full Text, Audio)

- Unceasing customer service

Track the below URL for one-step submission https://juniperpublishers.com/online-submission.php 